\title{
STUDI USAHA TANI KELAPA SAWIT PETANI DI DESA SALIKI KECAMATAN MUARA BADAK BERDASARKAN PRODUKSI TBS DAN HARGA SAWIT
}

\section{STUDY OF OIL PALM FARMING BUSINESSES IN SALIKI VILLAGE, MUARA BADAK DISTRICT BASED ON FFB PRODUCTION AND PALM OIL PRICES}

\author{
Rizal Abdul Harisma ${ }^{1}$, Sukariyan ${ }^{1 *}$, Abdul Rasyid Zarta ${ }^{1}$ \\ ${ }^{1}$ Politeknik Pertanian Negeri Samarinda, Kampus Gunung Panjang, Jl. Samratulangi, \\ Samarinda, Indonesia \\ *corresponding sukariyan971@gmail.com
}

\begin{abstract}
This research is based on the background that oil palm plantations are a form of community farming that cultivates oil palm plants with production in the form of fresh fruit bunches (FFB) as one of their sources of livelihood, although investment in oil palm plantations requires a relatively long period of time compared to oil palm plantations. with other plantation commodities. The purpose of this study was to determine the oil palm farming business in Saliki Village based on FFB production and palm oil prices. The data collection method used in this study is a qualitative method, which is a research that is used if the research factors cannot be quantified or cannot be calculated so that the variables cannot be expressed with numbers such as perceptions, opinions, assumptions and so on. According to qualitative research theory, in order for the research to be of really high quality, the data collected must be complete, namely primary data and secondary data. From the results of this study, it can be concluded that oil palm farming in Saliki Village based on the production of fresh fruit bunches and the price of palm oil really helps farmers increase their income from farming by selling large quantities of produce and high selling prices. The income they generate from oil palm plantations can meet their daily needs. In addition, the community (oil palm farmers) can buy vehicles, renovate and even build houses from the results of the oil palm plantations. The results of this study are to provide information to the community in Saliki Village in order to be able to improve oil palm farming.
\end{abstract}

Keywords: Farming Business, FFB Production, Price

\section{PENDAHULUAN}

Perkebunan kelapa sawit merupakan salah satu bentuk usaha tani masyarakat yang membudidayakan tanaman kelapa sawit dengan hasil produksi berupa tandan buah segar (TBS) sebagai salah satu sumber mata pencaharian mereka walaupun investasi perkebunan kelapa sawit memerlukan jangka waktu yang relatif lama dibandingkan dengan komoditi perkebunan yang lainnya.

Dalam suatu proses produksi sangat diperhatikan faktor-faktor produksi yang ada, tanpa salah satu dari semua faktor produksi tersebut proses produksi tidak dapat berjalan selain itu pengaruh suatu manajemen yang baik dapat mendukung proses tersebut.

Menurut Anonim (2008) harga adalah nilai suatu barang yang ditentukan atau dirupakan dengan uang. Harga adalah sejumlah uang seseorang yang harus membayar untuk mendapatkan produk.

Adapun tujuan dari penelitian ini untuk mengetahui usaha tani kelapa sawit di Desa Saliki berdasarkan produksi TBS dan harga sawit. Hasil yang diharapkan dari penelitian ini dapat memberi informasi 
kepada masyarakat di Desa Saliki agar mampu meningkatkan usaha tani.

\section{METODOLOGI}

\section{Metode Pengumpulan Data}

Penelitian ini menggunakan model penelitian kualitatif. Penelitian kualitatif bertujuan memperoleh gambaran seutuhnya mengenai suatu hal menurut pandangan manusia yang diteliti. Penelitian kualitatif berhubungan dengan ide, persepsi, pendapat, atau kepercayaan orang yang diteliti; kesemuanya tidak dapat diukur dengan angka (SulistyoBasuki, 2006:78)

\section{Prosedur Penelitian}

Tahap observasi partisipan, Peneliti melakukan pengamatan langsung dengan membawa data observasi yang telah disusun sebelumnya untuk melakukan pengecekan kemudian peristiwa yang diamati dicocokkan dengan data observasi.

Tahap wawancara terstruktur, Peneliti harus mengajukan pertanyaan yang sama dengan urutan yang sama kepada semua responden agar menimbulkan tanggapan yang sama sehingga tidak menimbulkan kesulitan pengolahan karena interpretasi yang berbeda.

Tahap dokumentasi, Peneliti melakukan dokumentasi pelaksanaan kegiatan penelitian melalui foto atau gambar, sebagai bukti fisik pelaksanaan penelitian.

Tahap tinjauan literatur, Peneliti membaca buku-buku yang dapat membantu peneliti melakukan penelitian untuk memperoleh data yang relevan. Tinjauan literatur digunakan sebagai bagian dari komponen teknik pengumpulan data.

\section{Analisis Data}

Analisis data kualitatif dilakukan apabila data empiris yang diperoleh adalah data kualitatif berupa kumpulan berwujud kata-kata dan bukan rangkaian angka serta tidak dapat disusun dalam kategori-kategori/struktur klasifikasi. Data bisa saja dikumpulkan dalam aneka macam cara (observasi, wawancara, intisari dokumen, pita rekaman) dan biasanya diproses terlebih dahulu sebelum siap digunakan (melalui pencatatan, pengetikan, penyuntingan, atau alih-tulis), tetapi analisis kualitatif tetap menggunakan kata-kata yang biasanya disusun ke dalam teks yang diperluas, dan tidak menggunakan perhitungan matematis atau statistika sebagai alat bantu analisis.

\section{HASIL DAN PEMBAHASAN}

ilmu usaha tani merupakan suatu ilmu yang mempelajari bagaimana menentukan, mengorganisasikan dan mengkoordinasikan dalam menggunakan sumberdaya dengan efektif dan efisien sehingga pendapatan yang diperoleh oleh petani lebih tinggi.

Setelah menjadi petani kelapa sawit masyarakat mengalami banyak perubahan dalam pendapatan mereka. Penggunaan hasil pendapatan usaha tani mereka gunakan untuk perluasan kebun, pendidikan anak, perluasan dan perbaikan rumah, pembelian kendaraan bermotor dan pembelian sarana perkebunan.

Berdasarkan banyaknya sampel untuk setiap usaha tani dan jenis kelamin dapat dilihat pada Tabel 1.

Tabel 1 Kelompok Tani Desa Saliki

\begin{tabular}{clccc}
\hline No & $\begin{array}{l}\text { Kelompok } \\
\text { Tani }\end{array}$ & Kelas & Anggota & Sampel \\
\hline 1 & $\begin{array}{l}\text { Cahaya } \\
\text { Mario }\end{array}$ & Pemula & 34 & 3 \\
2 & $\begin{array}{l}\text { Mekar } \\
\text { Sejahtera }\end{array}$ & Pemula & 76 & 7 \\
3 & $\begin{array}{l}\text { Setia } \\
\text { Kawan }\end{array}$ & Pemula & 50 & 5 \\
\hline & Total & & 160 & 15 \\
\hline
\end{tabular}

Dalam bidang perkebunan, tenaga kerja merupakan faktor produksi kedua 
setelah lahan. Penggunaan tenaga kerja dinyatakan dalam besaran curahan hari kerja, yaitu curahan hari kerja dari tenaga kerja efektif yang terpakai. Sumber tenaga kerja berasal dari dalam keluarga dan luar keluarga. Menurut Nu'man (2009) tenaga kerja perkebunan kelapa sawit merupakan salah satu faktor produksi yang menyerap biaya cukup besar sehingga perlu upaya untuk meningkatkan efisiensi.

Tanaman kelapa sawit ini banyak memberikan keuntungan asalkan rajin merawatnya. Hal tersebut terbukti dari hasil wawancara dengan Bapak Haris Sirajuddin sebagai petani kelapa sawit, yang mengatakan:

"penghasilan untuk luas lahan 5 hektar mencapai $R p$ 4.600.000 sampai $R p$ 23.000.000 per bulan, dengan hasil produksi yang mencapai 2,3 ton sampai 11,3 ton perbulan dengan 2 kali panen dalam sebulan. Tingkat keuntungan sawit lebih tinggi sehingga pendapatan saya menjadi lebih meningkat, karena itulah saya memilih untuk menjadi petani kelapa sawit".

Berdasarkan kendala yang di hadapi oleh sebagian besar masyarakat dalam pengelolaan perkebunan kelapa sawit dimana proses awal pembukaan lahan, harga sawit yang sering mengalami naik turun dan terjadinya trek, maka masyarakat melakukan berbagai upaya dalam mengatasi permasalahan tersebut agar dapat meingkatkan hasil dari produksi kelapa sawit sehingga dapat meningkatkan pendapatan dari perkebunan kelapa sawit tersebut.

Seperti yang kita ketahui jika ada permasalahan tentu ada juga solusi atau upaya yang akan dilakukan untuk memecahkan permasalahan tersebut, sama halnya dengan kendala-kendala yang di hadapi oleh masyarakat atau para petani Kelapa sawit di Desa Saliki.

Adapun mengenai upaya yang harus dilakukan untuk meningkatkan usaha tani para petani kelapa sawit di Desa Saliki menurut hasil wawancara peneliti dengan para petani kelapa sawit dan orang-orang yang terkait.

Seperti halnya yang di sampaikan oleh Bapak Ahmad Faisal: "mengenai kesulitan biaya dalam pembukaan perkebunan kelapa sawit, sebenarnya petani bisa meminjam uang ke toke (tokoh koperasi) kelapa sawit, tetapi dengan catatan bahwa petani tersebut harus menjual hasil panennya ke toke tersebut".

Seperti hal nya yang di sampaikan oleh bapak Rabani sebagai petani kelapa sawit, yang mengatakan:

"dalam usaha tani kelapa sawit ini mendapat dampingan dari pemerintah, setiap dua tahun sekali diadakan penyuluhan dan pembentukan kelompok tani".

Berikut yang di sampaikan oleh bapak Basri sebagai petani kelapa sawit, mengatakan:

"dulu pernah diadakan penyuluhan khusus perkebunan kelapa sawit yang membahas tentang pemilihan pupuk sawit yang tepat, yaitu pilih pupuk yang berfungsi untuk menunjang pertumbuhan dan perkembangan akar tanaman, dapat meningkatkan daya tahan tanaman sawit menjadi lebih kuat bahkan dalam kondisi ekstrem".

Dalam memilih dan menentukan pupuk seperti apa yang baik untuk buah kelapa sawit harus benar-benar dilakukan dengan tepat agar hasil buah sawit menjadi meningkat. Jika tanaman sawit dapat tumbuh dengan baik, maka harapan untuk mendapatkan budidaya kelapa sawit akan semakin dekat pada kesuksesan.

Usaha tani kelapa sawit di Desa Saliki Kecamatan Muara Badak, petani kelapa sawit sangat merasakan peningakatan dari usaha tani, karena membuka lapangan pekerjaan bagi masyarakat di Desa Saliki , yang memiliki tamatan atau ijazah SD, SMP, SMA hingga lulusan $S 1$, pendapatan yang mereka hasilkan dari perkebunan kelapa sawit dapat memenuhi kebutuhan mereka, sehingga yang dulunya tidak mampu untuk melanjutkan pendidikan anaknya kejenjang yang lebih tinggi sekarang akhirnya bisa dikarenakan pendapatan yang dihasilkan dari usaha tani kelapa sawit, selain itu masyarakat (petani kelapa 
sawit) bisa membeli kendaraan, merenovasi dan bahkan membangun rumah dari hasil perkebunan kelapa sawit tersebut. Namun tidak bisa dipungkiri jika dalam setiap usaha mengalami berbagai kendala atau masalah, demikian juga dengan usaha masyarakat dalam perkebunan kelapa sawit seperti kendala atau kesulitan yang dihadapi saat membuka lahan perkebunan kelapa sawit yang memerlukan modal cukup besar, terjadinya penurunan harga yang tidak menentu yang membuat petani resah, dan turunnya hasil produksi dari tandan buah sawit yang dipanen. Tapi hal tersebut tidak langsung membuat petani berhenti dalam usaha tani kelapa sawit, masyarakat melakukan berbagai upaya dalam mengatasi kendala-kendala yang terjadi, seperti melakukan kerjasama antara petani kelapa sawit dengan pihak perusahaan atau PT, lebih jeli dalam memilih bibit dan pupuk yang baik.

\section{KESIMPULAN}

Dari hasil penelitian ini dapat disimpulkan bahwa usaha tani kelapa sawit di Desa Saliki berdasarkan produksi tandan buah segar dan harga sawit sangat membantu petani meningkatkan pendapatan mereka dari usaha tani dengan penjualan hasil produksi yang banyak dan harga jual yang tinggi. Pendapatan yang mereka hasilkan dari perkebunan kelapa sawit dapat memenuhi kebutuhan mereka sehari-hari. Selain itu masyarakat (petani kelapa sawit) bisa membeli kendaraan, merenovasi dan bahkan membangun rumah dari hasil perkebunan kelapa sawit tersebut. Hasil penelitian ini untuk memberi informasi kepada masyarakat di Desa Saliki agar mampu meningkatkan usaha tani kelapa sawit. Diharapkan adanya upaya pemerintah/perusahaan untuk memberi bantuan berupa pupuk subsidi kepada para petani yang yang mengalami kendala perawatan lahan pertanian pada masa sulit seperti harga sawit yang menurun dan hasil panen yang mengalami penurunan. Diharapkan adanya pertimbangan pemerintah dan pihak terkait untuk tidak menurunkan harga sawit terlalu rendah karena akan menyusahkan masyarakat selaku petani kelapa sawit. Masyarakat harus pandai mengelola keuangan dan tidak meghamburkan uang pada saat harga sawit tinggi dan hasil panen melimpah, masyarakat harus berpemikian kedepan dan menabung, agar jika harga sawit menurun dan hasil panen juga menurun masyarakat tidak mengalami kesulitan untuk memenuhi kebutuhan sehari-hari karena sudah memiliki tabungan.

\section{DAFTAR PUSTAKA}

Anonim. 2008. Kamus Besar Bahasa Indonesia . Jakarta. h. 510.

Basuki, Sulistyo. 2006. Metode Penelitian. Jakarta: Wedatama Widya Sastra

Nu'man, M. 2009. Pengelolaan Tenaga Kerja Perkebunan Kelapa Sawit (Elaeis guineensis Jacq.) di Perkebunan PT Cipta Futura Plantation, Muara Enim, Sumatera Selatan. Skripsi. Institut Pertanian Bogor. Bogor 